This PDF is a selection from an out-of-print volume from the National Bureau of Economic Research

Volume Title: Long-Range Economic Projection

Volume Author/Editor: Conference on Research in Income and Wealth

Volume Publisher: NBER

Volume ISBN: 0-691-04141-5

Volume URL: http://www.nber.org/books/unkn54-1

Publication Date: 1954

Chapter Title: Problems of Estimating Spending and Saving in Long-Range Projections

Chapter Author: Mary W. Smelker

Chapter URL: http://www.nber.org/chapters/c2937

Chapter pages in book: (p. 333 - 364) 


\title{
PROBLEMS OF ESTIMATING SPENDING AND SAVING IN LONG-RANGE PROJECTIONS
}

\author{
MARY W. SMELKER \\ RENYX, FIELD \& COMPANY, INC.
}

\section{A. INTRODUCTION}

UNDER the Employment Act of 1946, the government of the 'United States obligated itself to adopt policies leading to "maximum employment, production and purchasing power." This involves the attempt to reduce cyclical fluctuations in magnitude, either through long-range policies or short-term devices. One important objective of a long-range projection is to find those dynamic relations which will promote fairly smooth economic development and minimize the necessity for short-term, arbitrary intervention in the economic system.

The use of the term "projection" rather than prediction or forecast indicates that the estimates are governed by some basic assumptions which may or may not be realized. In this case the assumption is that of relatively full employment and gradually rising real incomes. The price level may be assumed to be constant or gradually rising; a gradually rising price level being, in the opinion of some, more conducive to steady economic expansion.

A full-employment projection is an ambitious undertaking at this stage of the development of economic analysis. Such an undertaking implies that at a minimum we have a fairly firm grasp of the historical causes of economic growth and cyclical downturns, whereas in actuality we are reminded every day of our inability to penetrate the subtleties and complexities of economic processes. Only the necessity, or at least the advisability, of providing a basic quantitative framework to guide public policies justifies the erection of such a superstructure upon our present foundation of knowledge. Further, if we are "projecting" a future of peaceful, sustained economic growth, this is a different environment than prevailed during most of the period in which

Note: At the time this paper was prepared, the author was a staff member of the Council of Economic Advisers, but bears full responsibility for the views expressed. The author wishes to express her appreciation to Mrs. Selma Goldsmith and Mrs. Rosalie Epstein for assistance and to Mr. Daniel Creamer for helpful criticism. 


\section{SPENDING AND SAVING}

fairly detailed economic observation has been possible. Since the turn of the century, the behavior of income, spending, and saving has been profoundly influenced by business cycles and wars. Consequently, a large element of subjective judgment must enter in adapting any information from recent periods to the conditions which are presumed or "assumed" to prevail in a more stable and peaceable future.

A further complication in projecting saving is introduced by the fact that it is almost impossible to make estimates of one segment of an economy without some fairly detailed assumptions about other areas. For example, the incurrence of a government surplus or deficit will affect consumer behavior. The government maintains, contracts, or enlarges its surplus by some positive action which affects directly or indirectly the household sector of the economy. The effects of tax changes or of increases in transfer payments on the distribution of consumer disposable income are cases in point. In addition, long-range government policies affecting social consumption, personal security, etc. are certain to have effects on consumer behavior of significant magnitude, while programs regarding slum clearance, public housing, and aid and support of private housing, price support programs, and even aid to small business may not be negligible.

The analysis of spending and saving in a long-range projection presents itself in two phases: (1) the selection of basic historic determinants of consumer behavior, and (2) the introduction of modifications, necessary because of the novelty of the assumption of continuous full employment.

It is appropriate to neglect those factors affecting consumer behavior which emanate from cyclical changes elsewhere in the economy. However, tendencies toward self-generating cycles, such as would be provided by excessive accumulations of stocks of consumer durable goods or liquid assets, are of the essence of the inquiry.

The principal problem about consumer behavior that has concerned analysts is the basis of the personal decision to spend or to save. The distribution of expenditures among different types of goods and the distribution of saving among assets of greater or less liquidity have received considerably less attention, although these questions are of scarcely less importance. In posing a sharp dichotomy between spending and saving, a distinction is made which appears to be critical for the analysis of business 
cycles, yet the point at which the distinction is drawn is somewhat arbitrary and may not be the best one from the standpoint of studying consumer behavior. Definitions of saving in current use in statistical inquiries may not correspond to the consumers' own concept of what saving is, and consequently may not be closely related to the bases of consumer choice, which in turn may cause behavior to appear more erratic, or even irrational, than it is. The distribution of funds at the command of consumers represents a continuum from expenditures which have only a small element of saving, such as those for clothing, through longlived durable goods, to liquid assets. A moving equilibrium at full employment involves the whole distribution of expenditures, or, rather, the whole pattern of personal sources and uses of funds. Not only does the accumulation of stocks which may be presumed to occur under high incomes pose problems of the maintenance of a high spending rate, but an economy with a high ratio of durable goods to total consumer expenditure will be a very different economy from one in which nondurables or, say, personal services are high. An economy where consumers invest most of their savings directly in homes or businesses may be more stable (but less "manageable") than one in which liquidity has a high premium and the services of financial intermediaries are required.

At the present time there is no theoretical structure regarding consumer behavior which is sufficiently general to provide for simultaneous determination of the whole pattern of consumer outlay. While we do have many of the elements of a theory of consumer behavior, contributed by the work of researchers in this field in the last 10 to 20 years, too much time has been directed to attempting to define, by empirical investigation of time series, regularities in the relation between some aggregation of saving components and a very limited number of other economic variables. Of this type of activity there is no end-the consumption functions which have been "fitted" to time series of inadequate length, often with little regard to the appropriateness of the definitions of income and saving underlying the inquiry, have already been numerous enough for special bibliographies.

The difficulties of discovering any stable or "projectable" relations by correlations of aggregates of income, other variables, and saving rest not only on the technical deficiencies of multicorrelation analysis, but also on the fact that the factors in the particular complex which is represented by movements in the 
independent variables throughout some observational periods may not be stable in their relations to each other. Thus, we often have no way of knowing whether we have observations on the same consumption function for successive years, or a new function. This is particularly true after a series of years punctuated by wars and depressions. On this score, cross section analyses of consumer budgets, using different types of families, different areas, etc., seem more likely to discover the fundamental regularities rooted in the psychological make-up of the consumer. Drawing inferences from relations between income and other variables discovered to exist at a moment in time and applying them to a situation involving changes through time is nevertheless beset with numerous pitfalls. The classic example of a fallacy resulting from mixing statics with dynamics was the conclusion that since income and the rate of saving are always positively correlated in consumer budgets, the secular growth in real incomes must be accompanied by a continually rising saving rate.

At the present time, out of a great surge of activity in the area of exploration of the "consumption function," following the rise to popularity of Keynesian economics, two propositions concerning consumer behavior have emerged which may be first discussed briefly as a taking off point for the discussion of projections. These propositions are singled out for special treatment because for a time it appeared that the two taken together formed an almost complete explanation of the course of spending and saving over the last 50 or 75 years, including both secular trends and cyclical deviations in the average rate of saving. The two are on quite different levels, the first having the character of a psychological law, at least in our culture, and the second being a matter of empirical observation, although the regularities observed are susceptible to plausible explanation. The first proposition is that the ratio of household saving to household income depends on the relative position of the family in the income scale of the community. Therefore, changes in the saving rate depend on changes in income distribution. The second is that the rate of saving has in this country been secularly constant despite pronounced yearto-year deviations arising from cyclical influences. 


\section{B. INFLUENCE OF RELATIVE INCOME POSITION ON THE RATE OF SAVING}

The ability to save, for most families, depends on the current flow of income. Nevertheless, empirical analysis of consumer budgets for a number of types of families in different years for which data are available indicates that the proportion of household income saved depends not on the income level of the family, but on the relative status of the family with respect to other families higher or lower in the income scale. ${ }^{1}$ Emulation of the spending habits of higher income groups, rather than the real standard of family living, determines the percent of income which will be saved. Thus, aside from transitory effects, an increase in real income will not affect family saving if other families in the community receive a proportional increase.

By aggregating the saving of households, according to this view, we arrive at an over-all national rate of saving which is directly related to the size distribution of income and changes in this distribution, but is independent of changes in real income. Other factors more or less unrelated to income may influence consumption over the business cycle, or its secular trend, but these are secondary and can be independently evaluated.

\section{SECULAR CONSTANCY OF THE SAVING RATIO}

When it was believed that saving depended on the level of real income, it followed that the growth in real income over the decades would lead to a secular growth in saving in relation to income. No such inherent tendency for saving to increase is implicit in the notion that saving depends on relative position in the income scale. Such data as have been available on long-run trends in investment, notably those of Simon Kuznets shown below, failed to indicate a secular growth in saving, casting doubt

1 The pioneering work in this area was done by Dorothy S. Brady and Rose D. Friedman. See their "Savings and the Income Distribution," in Studies in Income and Wealth, Volume Ten (NBER, 1947). Independent work was also done by James S. Duesenberry, who developed the dynamic implications of the theory. See his Income, Saving, and the Theory of Consumer Behavior, Harvard Economic Studies, No. 87 (Harvard University Press, 1949). 


\section{SPENDING AND SAVING}

on the validity of the former theory, if not exactly confirming the latter. $^{2}$

Actually, the Kuznets data cannot establish anything very positive about trends in personal saving because of the changing external factors affecting consumer behavior over the observation period. The thirties must be omitted from consideration because of the magnitude and length of the depression. The period of the First World War is also irrelevant because the federal government ran a large deficit for several years. Thus the three decades previous to the First World War and the twenties are left for observation of the trend. While the rate of saving for the economy as a whole during these decades shows no clear relation to time, a change in the contribution of corporate and government saving to the total national saving might have obscured an upward trend. Furthermore, there may be more or less random shifts in the consumption function from time to time, which, although not inconsistent with long-range constancy in the saving ratio, are of a magnitude which is fairly crucial for the maintenance of employment in the short run.

Although direct statistical evidence for the secular constancy of the ratio of saving to income is not very satisfactory, an ingenious argument may be made resting the conclusion on the better-established proposition that variations in saving depend on variations in the concentration of income. If the rate of saving is determined by the distribution of income and, in fact, the distribution of income has been constant, the rate of saving in relation to income would tend to be constant also. (The influence of an increasing degree of urbanization and a changing age distribution of the population, both long-term secular trends affecting saving, will be discussed later.)

The long-term constancy of the income distribution is not a matter of historical evidence, however. Data are scanty, and even for interwar periods relate mostly to the upper segments of the population. One conclusion that seems fairly well verified is that a significant shift toward lesser concentration of income (as measured by the Lorenz curve) has taken place since the twenties. A priori, there seems no reason to believe that the process

2 This fact was independently observed by Modigliani and Duesenberry at about the same time. See Franco Modigliani, "Fluctuations in the Savings Ratio: A Problem in Economic Forecasting," Studies in Income and Wealth, Volume Eleven (NBER, 1949); and Duesenberry, op.cit. 


\section{SPENDING AND SAVING}

TABLE 1

Percentage Distribution of National Income between

Flow of Goods to Consumers and Net Capital Formation, 1869-1938

\begin{tabular}{|c|c|c|c|c|c|}
\hline LINE & DECADE & $\begin{array}{l}\text { C U R R E N } \\
\text { Flow of } \\
\text { Goods to } \\
\text { Consumers } \\
\text { (1) }\end{array}$ & $\begin{array}{l}\text { P R I CES } \\
\text { Net } \\
\text { Capital } \\
\text { Formation } \\
(2)\end{array}$ & $\begin{array}{l}1929 \\
\text { Flow of } \\
\text { Goods to } \\
\text { Consumers } \\
\text { (3) }\end{array}$ & $\begin{array}{c}\text { P R I E S } \\
\text { Net } \\
\text { Capital } \\
\text { Formation } \\
(4)\end{array}$ \\
\hline $\begin{array}{l}1 \\
2 \\
3 \\
4 \\
5\end{array}$ & $\begin{array}{l}1869-78 \\
1874-83 \\
1879-88 \\
1884-93 \\
1889-98\end{array}$ & $\begin{array}{l}87.9 \\
87.0 \\
86.8 \\
85.9 \\
85.9\end{array}$ & $\begin{array}{l}12.1 \\
13.0 \\
13.2 \\
14.1 \\
14.1\end{array}$ & $\begin{array}{l}86.3 \\
85.6 \\
85.4 \\
83.9 \\
83.8\end{array}$ & $\begin{array}{l}13.7 \\
14.4 \\
14.6 \\
16.1 \\
16.2\end{array}$ \\
\hline $\begin{array}{r}6 \\
7 \\
8 \\
9 \\
10\end{array}$ & $\begin{array}{l}1894-1903 \\
1899-1908 \\
1904-13 \\
1909-18 \\
1914-23\end{array}$ & $\begin{array}{l}86.4 \\
87.4 \\
87.9 \\
87.5 \\
87.6\end{array}$ & $\begin{array}{l}13.6 \\
12.6 \\
12.1 \\
12.5 \\
12.4\end{array}$ & $\begin{array}{l}85.2 \\
86.4 \\
86.9 \\
87.0 \\
88.6\end{array}$ & $\begin{array}{l}14.8 \\
13.6 \\
13.1 \\
13.0 \\
11.4\end{array}$ \\
\hline $\begin{array}{l}11 \\
12 \\
13\end{array}$ & $\begin{array}{l}1919-28 \\
1924-33 \\
1929-38\end{array}$ & $\begin{array}{l}89.1 \\
93.3 \\
98.0\end{array}$ & $\begin{array}{r}10.9 \\
6.7 \\
2.0\end{array}$ & $\begin{array}{l}89.8 \\
94.0 \\
98.6\end{array}$ & $\begin{array}{r}10.2 \\
6.0 \\
1.4\end{array}$ \\
\hline \multicolumn{6}{|c|}{ Averages } \\
\hline $\begin{array}{l}14 \\
15 \\
16\end{array}$ & $\begin{aligned} & \text { Lines } 1-5 \\
& 5-9 \\
& 9-13\end{aligned}$ & $\begin{array}{l}86.7 \\
87.0 \\
91.1\end{array}$ & $\begin{array}{r}13.3 \\
13.0 \\
8.9\end{array}$ & $\begin{array}{l}85.0 \\
85.9 \\
91.6\end{array}$ & $\begin{array}{r}15.0 \\
14.1 \\
8.4\end{array}$ \\
\hline $\begin{array}{l}17 \\
18 \\
19\end{array}$ & $\begin{array}{l}1-5 \\
4-8 \\
7-11\end{array}$ & $\begin{array}{l}86.7 \\
86.7 \\
87.9\end{array}$ & $\begin{array}{l}13.3 \\
13.3 \\
12.1\end{array}$ & $\begin{array}{l}85.0 \\
85.3 \\
87.8\end{array}$ & $\begin{array}{l}15.0 \\
14.7 \\
12.2\end{array}$ \\
\hline
\end{tabular}

Source: Simon Kuznets, National Income: A Summary of Findings (NBER, 1946), p. 53.

of industrialization and urbanization which took place over the last century did not produce significant shifts in the distribution of income in earlier decades.

In addition, it is doubtful whether the income distribution theory of saving is a theory of economic dynamics which could be expected to explain long-term changes. The behavior described in the theory rests on patterns of social and economic emulation. "What a family spends depends on what it sees others possess; new products are bought first by upper income groups, and later by those lower down on the income scale."

Emulation and competitive living are deeply imbedded in our social structure; but the influence of these factors might be expected to have varied a good deal as the economy and the culture 


\section{SPENDING AND SAVING}

have passed through successive historical phases. ${ }^{3}$ The same objection (namely, that other things cannot be assumed to remain equal) which applies to the now discarded view that saving depends on the level of real income applies, though with less force, to the "relative income" theory, if it is used to explain events widely separated in time. A general reduction in the extremes of income would not only change the rate of saving, but probably also the pattern of emulation. The process of cultural diffusion in a society in which income is concentrated around the mode would undoubtedly be very different from that in a society in which the income distribution is more unequal. ${ }^{4}$ Other unrelated historical factors may be thought of which would tend to alter the general structure of social emulation, such as the trends toward greater leisure and toward ease and rapidity of movement from town to country.

If it were possible to construct a system encompassing all possible influences on the consumer psyche, we could then speak of the "consumption function" as though it were immutable. When variables affecting spending are reduced to a manageable number, the possibility of short-term shifts, or even trends, in a statistically determined saving function cannot be excluded. The view that the saving ratio remains constant from cycle to cycle won ready acceptance because of the dilemma involved in projecting a rising saving rate as real income increases secularly. The alternative to a rising rate may be, however, not constancy, but upward or downward shifts from period to period in the consumption function, which over a period of years may be largely offsetting. Since historical shifts in the "propensity to consume" cannot be ruled out, a projection of saving in a fullemployment economy should give more weight to the pattern of spending and saving in recent years of full employment, with such qualitative adjustments as may be indicated by the special circumstances of those years, than to secular averages or trends.

3 Brady and Friedman found that the pattern of spending by relative income level did vary considerably from 1901 to 1935-36 and 1941. Sample differences may have affected this conclusion.

4 This fact was recognized by those analyzing the data collected in 193536 on family budgets who remarked that "the number of families at each income level is, in itself, one factor influencing spending patterns. Keepingup-with-the-Joneses might take on new and unprecedented forms if the distribution of income should approach much more nearly to equality." Consumer Expenditures in the United States (National Resources Committee, March 1939), p. 163. 


\section{SPENDING AND SAVING}

\section{SAVING IN RECENT YEARS OF FULL EMPLOYMENT}

Although the best guide to what consumers will do if full employment and rising incomes are maintained for 5 to 10 years probably lies in recent experience, the question arises whether saving patterns in past years of "full employment," when such years fall at the peak of a business cycle, can be relied on in making estimates of what would happen were full employment to be continuously maintained. The rate of saving is always high in relation to current income in prosperous years, which fact may reflect, among other things, a lag in expenditures behind rising incomes, shifts in the degree of income concentration, or shifts of income to occupational groups with high average or marginal rates of saving. An appraisal of those cyclical influences might lead to the conclusion that in peak years of the cycle the rate of saving is forced above the level it would tend to attain if the same levels of income could be continuously maintained.

On the other hand, there is one factor which tends to make saving during the peak years of a business cycle lower than it might be under conditions of continued prosperity. This factor is the bunching of durable goods expenditures in these years. Changes in the rate of purchases of durable goods involve an increase in the rate of credit utilization, which, other things being equal, causes net saving to decline temporarily-until the higher rate of repayments catches up with the rate of new credit utilization. Dipping into liquid assets to purchase durables has a somewhat similar effect. Such changes act as a depressant of the rate of saving in peak years of the business cycle, and, to some extent, offset other factors which might cause the rate of saving to be unusually high in these years.

The maintenance of general expansion in an economy would require as a condition (and tend to achieve as a result) a smoothing out of not only the rate of capital formation, but also the production of consumer durable goods. For this reason, and also, as will be discussed later, because the lag of expenditures behind incomes in years of rising income is probably small, it seems reasonable that the saving rate under continued full employment would not be substantially below that in past years of full employment.

Until 1951, observations of saving rates in years of relatively 


\section{SPENDING AND SAVING}

full employment in the last 20 years have shown remarkably little dispersion, especially considering that errors in estimating personal saving are relatively large. In 1948 the ratio of saving to income was about 5.6 percent, compared with 4.9 percent in 1940 , 5.5 percent in 1937, and 4.5 percent in 1929. If farm inventory changes are excluded from income and saving, the ratio between saving and disposable income was just about 5 percent in 1929, 1937, 1940, 1948, and 1950 (Table 2). ${ }^{5}$

\section{TABLE 2}

Relation between Personal Saving and Income in YeARS OF HrGH EMPLOYMENT, 1929-51 (IN PERCENT)

\begin{tabular}{ccc}
\hline Year & $\begin{array}{c}\text { National } \\
\text { Income } \\
\text { Concept }\end{array}$ & $\begin{array}{c}\text { National Income Concept } \\
\text { Excluding Increase } \\
\text { in Farm Inventory }\end{array}$ \\
\hline 1929 & 4.5 & 4.8 \\
1937 & 5.5 & 4.8 \\
1940 & 4.9 & 4.6 \\
1946 & 7.6 & 7.7 \\
1947 & 2.3 & 3.6 \\
1948 & 5.6 & 5.1 \\
1949 & 3.4 & 3.9 \\
1950 & 5.2 & 5.1 \\
1951 & 8.3 & 7.7 \\
\hline
\end{tabular}

a The net increase in farm inventories has been subtracted from disposable income and saving.

Source: Department of Commerce.

In 1951, there was an abrupt upward shift in the saving rate beginning in the second quarter. On the basis of preliminary estimates, it appears that saving may have amounted to over 9 percent of disposable personal income in the last three quarters of the year. The suddenness and magnitude of the shift (which was largely an increase in liquid saving) occasioned great surprise, although a gradual rise in saving appeared probable as postwar backlogs of durables were exhausted.

A number of special factors may have operated to cause a temporary bulge in the rate of saving in 1951, such as adverse reactions to the rise in prices and the buying waves which characterized late 1950 and early 1951. The loss of liquidity in the

5 The exclusion of farm inventories is based on the supposition that accretions to farm inventories are largely involuntary, and that if the inventory had been sold, only part of the proceeds would have been saved. 


\section{SPENDING AND SAVING}

personal economy which had been going on since the end of the war may have been an important reason for a temporary increase in financial types of saving. In addition to these factors, however, it is impossible to dismiss the hypothesis that there may have been a downward shift in the consumption function, and that this shift may be of considerable duration. And if, indeed, the full-employment saving ratio is now higher than it was prewar, the level of real income can no longer be ruled out as a major determinant of saving. More weight is given to this possibility of a shift in the consumption function by the fact that in the period 1946 through 1950 the saving rate was not especially low, though there were important factors, such as backlog demands for durable goods and high liquidity, which should have depressed it. A downward shift may have been concealed by the satisfaction of backlog demands in the earlier postwar years, only to show up in 1951 as these demands decreased in intensity.

If present high levels of per capita real income are maintained and increased, on the other hand, it is quite possible that increasing family security and confidence in economic stability will weaken the motive for accumulation.

\section{E. FACTORS TENDING TO INFLUENCE THE RATE OF SAVING}

On the following pages some of the factors which might cause the saving rate to change from the pattern of recent years are examined. These are: changes in the concentration of income, changes in the age distribution of the population, changes in income level, a changing degree of urbanization, changes in price level, changes in stocks of financial assets, and changes in stocks of consumer durables.

\section{Changes in the concentration of income}

Over a considerable span of years it is likely not only that the distribution of income by size will change, but also that the significance of a given relative status in the distribution, so far as it affects consumption, will also change. On the other hand, over the shorter run of 5,10 , or perhaps 20 years, assuming the social and psychological climate is not greatly altered, it seems plausible to suppose that a changing concentration of income will be related to the saving rate in a systematic way. For example, it 


\section{SPENDING AND SAVING}

is reasonable to suppose that if a higher proportion of total income is received by the "poorer" half of the population (in terms of income), a decline in the average over-all saving rate will ensue. ${ }^{6}$

Nevertheless, data drawn from recent sample studies do not encourage the belief that there is a very stable relation between income position and saving. Table 3 shows savings ratios by quintiles of the total population of spending units for the years 1946 through 1950 drawn from the annual Survey of Consumer Finances. These were years of marked stability in the income distribution. All were years of rising income except 1949, when, despite general stability of income, farm income dipped substantially.

TABLE 3

Distribution of Income and Saving among Income Fifths, 1946-50

\begin{tabular}{lrrrrrrrrrr}
\hline SPENDING & \multicolumn{4}{c}{ PERCENT OF TOTAL INCOME } & \multicolumn{4}{c}{ PERCENT OF PERSONAL SAVING } \\
UNITS & 1946 & 1947 & 1948 & 1949 & 1950 & 1946 & 1947 & 1948 & 1949 & 1950 \\
\hline Lowest fifth & 4.5 & 4.3 & 4.7 & 3.9 & 4.1 & -8.1 & -12.6 & -22.2 & -40.9 & -17.2 \\
Second fifth & 10.7 & 10.2 & 11.3 & 10.9 & 11.2 & 3.4 & 0.9 & -3.3 & -12.2 & 0.9 \\
Third fifth & 16.1 & 15.6 & 16.3 & 16.8 & 17.1 & 5.5 & 7.7 & 7.5 & 1.2 & 3.0 \\
Fourth fifth & 22.3 & 21.6 & 22.0 & 23.1 & 23.5 & 20.7 & 10.9 & 20.8 & 21.3 & 20.8 \\
Highest fifth & 46.4 & 48.3 & 45.6 & 45.3 & 44.1 & 78.5 & 93.1 & 97.2 & 130.6 & 92.5 \\
All units & 100.0 & 100.0 & 100.0 & 100.0 & 100.0 & 100.0 & 100.0 & 100.0 & 100.0 & 100.0 \\
\hline
\end{tabular}

Details may not add to totals because of rounding.

Source: Survey of Consumer Finances (Board of Governors of the Federal Reserve System).

The shifts in the proportion of saving performed by each fifth of the population in the period 1946 through 1950 were much greater than the shifts in the income distribution. This suggests that the basic relation between relative income and expenditures

6 This is a "common sense" proposition, which could only be verified by assuming "other things equal" under circumstances where this assumption would hardly be justified. A test was made of the effects of income redistribution, on the hypothesis that the saving rate depends exclusively on relative income, by applying 1949 saving rates per decile (as estimated in the Survey of Consumer Finances) to the 1941 size distribution of income by deciles, and secondly to the 1949 distribution. The somewhat more concentrated income distribution in 1941 gave a 6 percent over-all saving rate, compared with 5 percent in 1949. Less significant results would have been obtained had there been less negative saving in the lower deciles of the income distribution in 1949. In any case, the relations between saving and income which have been observed historically can be applied only to relatively small changes in income concentration. 


\section{SPENDING AND SAVING}

which is reflected in budgetary studies is overlaid by a network of dynamic influences, which in the short run are more important than shifts in income distribution in causing variations in the saving rate. The distribution of income may remain quite stable from year to year while the degree to which individuals and families are shifting up or down the income scale may be much larger in some years than in others. For example, there was no marked change in the income distribution from 1948 to 1949 , or from 1949 to 1950 , but 1949 may have been characterized by much more "displacement" of individual families from their usual position in the income scale. It is known that much of the dissaving at the lower end of the income scale was performed by farmers with large declines in income.

In general, the income distribution alone supplies little information concerning the causes of changing saving rates. Some sort of index of the degree of internal "displacement" or migration of families up or down the income scale would probably be much more useful. While we have become accustomed to the fact that the lower income segments always contain disproportionately large numbers of families who are experiencing a decline in income, we have little notion of how much dissaving, year after year, could take place, or is likely to take place, because of the regular infiltration of the lower income groups by families with reserves of assets. The rate of dissaving in the lower income groups which could be sustained year after year by drawing on accumulated assets or future income may on the average be much smaller than the rate in the post-World War II period. One method of determining whether dissaving represents exhaustion of resources by units normally in a given income class, or merely reduces the new assets being brought into an income class by units with declines in income, would be the preparation of financial balance sheets by income class at intervals of a year or more.

Notwithstanding the inconclusiveness of the evidence thus far, there is still a presumption that a shift in the distribution of income toward reduced concentration will result in a lowering of the saving rate. The assumption chosen with regard to the distribution of income in any model or projection must, of course, be consistent with other aspects of the model, particularly with the distribution of the national income by functional shares and the tax structure. ${ }^{7}$

${ }^{7}$ While the relationship between changes in the relative proportions of 


\section{Changes in the age distribution of the population}

It has long been recognized that saving may be affected by changing proportions of the elderly and retired to total population. Dorothy Brady observes, "In the longer run, the general aging of our population promises to alter the relationships of national income, expenditures, saving, and investment significantly." considerable data of a type not previously available relating saving to the cycle of marriage, purchase of home and household equipment, provision for old age, and retirement.

These data suggest that the saving behavior of the 18-24 age group varies as much from that of the middle age groups as does that of the over- 65 group. The older people have an exceptionally high frequency of zero savings, but the frequency of negative savings was greatest in the younger age groups in 1948 and 1949. In those years, the 18-24 age group (which contained about the same proportion of total consumer units as the over65 group) had significant negative net savings, whereas the over65 group had significant positive savings. In 1950, on the other hand, the 18-24 age group accounted for a slightly higher fraction of total net savings ( 2 percent) than did the oldest age group. ${ }^{9}$

The high frequency of dissaving among the 18-24 age group, and to a lesser extent among the 25-34 age group, reflects in many cases purchases of durable goods incident to setting up a household. As is shown in the 1950 Survey of Consumer Finances, the purchase of durable goods has a clear relation to the number of years a couple has been married.

It is sometimes remarked that an increasing proportion of aged in the population may lead to a lower over-all rate of saving. During the next 10 to 15 years, however, a changing age distribu-

the distributive shares of national income and in the distribution of income by size are not known in detail, it is likely that an increase in the ratio of farm income and/or wages and salaries to dividends, profits, and rent will produce a decrease in the inequality of the size distribution. Aspects of this problem were discussed in my paper "Shifts in the Concentration of Income," in Review of Economics and Statistics, Vol. xxx, No. 3, August 1948.

8 Dorothy S. Brady, "Influence of Age on Family Savings," Current Economic Comment, Vol. 11, No. 4 (University of Illinois, 1949), p. 51.

9 "1951 Survey of Consumer Finances," Federal Reserve Bulletin, September 1951, part Iv, table 16. Also published as a separate report, 1951 Survey of Consumer Finances. 


\section{SPENDING AND SAVING}

tion of population should work in the opposite direction. For example, as shown in Table 4, it is likely that by 1960 the increase in the proportion of aged to total adult population will be largely offset, as far as saving is concerned, by a drop in the proportion of young people. The 20-24 age group, who tend to be dissavers, and the 25-34 age group, who are only moderate savers, will decline in absolute numbers. The heavy savers, the $35-64$ age group, will represent a larger proportion of the adult population than at present.

It would be a mistake, however, to concentrate on age to the exclusion of factors which change the saving significance of a given age group, such as earlier retirement or a change in the age of marriage. Early marriage seems to be a feature of a fullemployment economy, but retirement may actually be postponed when times are good and jobs plentiful.

TABLE 4

U.S. Population, Including Armed Forces Overseas, Actual 1950 and Projected 1960

\begin{tabular}{lcc}
\hline \multicolumn{1}{c}{ Age Groups } & $\begin{array}{c}1950, \\
\text { Actual }\end{array}$ & $\begin{array}{c}1960, \\
\text { Projected }^{\mathrm{a}}\end{array}$ \\
\hline Under 19 years & \multicolumn{2}{c}{ (thousands) } \\
20-24 years & 52,480 & 61,796 \\
25-34 years & 11,732 & 11,426 \\
$35-64$ years & 23,717 & 22,629 \\
65 and over & 52,160 & 59,746 \\
$\quad$ Total population & 11,600 & 15,578 \\
$\quad$ Total population over 20 years & 151,689 & 171,176 \\
Population aged 65 and over & 99,209 & 109,380 \\
Population over 65 and between 20 and 25 & 23.5 & 14.2 \\
Population 35-64 & 52.6 & 24.7 \\
\hline
\end{tabular}

a Medium assumptions with regard to rates of fertility, mortality, and net immigration.

Source: Bureau of the Census.

\section{Changes in income level}

In addition to income level, changes in income have long been recognized as a factor having considerable importance in determining spending or saving. J. R. Hicks, in his recent book on the trade cycle, ${ }^{10}$ suggests that the true relation between income and

${ }^{10} \mathrm{~J}$. R. Hicks, A Contribution to the Theory of the Trade Cycle (Oxford University Press, 1950). 
saving is a lagged relation (i.e., current income determines saving in the next period) and that the use of current income and saving in a regression over- or underestimates the marginal propensity to save.

The proposition that the aggregates should be related on a lagged basis rests on the view that families whose incomes have recently increased to a given level will spend less than families whose incomes have been stable at that level, and that, in turn, families with incomes that have been stable at a given level will spend less than families whose incomes have recently declined to that level.

The use of a lagged relation between income and saving has the advantage of getting around the ambiguity of the term "marginal propensity to save." While income increases or decreases may give rise to variations in saving which are temporarily disproportionate to the change in income (and this is important for the business cycle), this phenomenon is not very adequately described by saying that the marginal rate of saving is rising. Once the new income level has become well established, the saving rate may revert to its former level.

The ability to compute even the short-run "marginal propensity to save," particularly in the postwar period, is complicated by shifts in the consumption function. However, the presence of large numbers of families with incomes which tend to fluctuate cyclically indicates that the saving rate will rise in years in which income rises generally. Families with fluctuating incomes, such as entrepreneurial groups and farmers, tend to stabilize their consumption and let the impact of income variations fall on saving. Changes in the incomes of these groups are synchronized with changes in the general income level, but are more extreme. It thus appears that a change in the level of income, even aside from lags, will cause a more than proportional variation in saving. Aside from this, of course, there may be lags in the adjustment of expenditure patterns among the more stable income groups.

The existence of a lag in expenditures has been confirmed by various studies, but it has also been found that there is an asymmetry between the effects of income increases and decreases on family saving. In 1948 Ruth Mack found that the lag of expenditures behind income for families with declining income was more pronounced than in the case of those with rising in- 


\section{SPENDING AND SAVING}

come. ${ }^{11}$ Data from the Survey of Consumer Finances also suggest this asymmetry. On the average, people with income decreases dissave more than people with constant incomes, and, on the average, dissave a higher percent of income. ${ }^{12}$ Families with income increases are more often savers than families with constant incomes, but income increases may also result in a high frequency of dissavers. In both 1948 and 1949, units with increases in income dissaved (as well as saved) more frequently than units with constant income (Table 5). ${ }^{13}$

\section{TABLE 5}

Percentage of Spending Units with Specific Changes in Income Having Positive, Zero, and Negative Savings, 1948, 1949, and 1950

\begin{tabular}{lccccccccc}
\hline CHANGE IN & \multicolumn{3}{c}{ POSITIVE SAVINGS } & \multicolumn{3}{c}{ ZERO SAVINGS $^{\mathbf{a}}$} & \multicolumn{3}{c}{ NEGATIVE SAVINGS } \\
INCOME & 1948 & 1949 & 1950 & 1948 & 1949 & 1950 & 1948 & 1949 & 1950 \\
\hline Large increase & 63 & 62 & 68 & 5 & 2 & 4 & 32 & 31 & 28 \\
Small increase & 67 & 66 & 64 & 5 & 4 & 5 & 28 & 30 & 31 \\
No change & 64 & 61 & 59 & 9 & 12 & 9 & 27 & 27 & 32 \\
Decline & 56 & 48 & 53 & 4 & 8 & 8 & 40 & 44 & 39 \\
\hline
\end{tabular}

a Obtained as a residual.

Source: Survey of Consumer Finances (Board of Governors of the Federal Reserve System).

This suggests that families with changes in income may be divided into two groups: those who regard the change as temporary, and those who regard it as permanent. The latter may dissave when income rises, feeling that they can now afford the new car or other item of expenditure which requires temporary credit, while the former may save an unusually large amount. When incomes in general have an upward trend, the former group will assume increased importance.

Modigliani and Duesenberry have suggested that it is the income of the previous peak year, rather than last year's income, which has a significant effect, in addition to current income, on

${ }^{11}$ Ruth P. Mack, "The Direction of Change of Income and the Consumption Function," Review of Economics and Statistics, Vol. $\mathrm{xxx}$, No. 4, 1948.

12 See George Katona, "Effect of Income Changes on the Rate of Saving," Review of Economics and Statistics, Vol. xxxI, No. 2, May 1949.

${ }^{13}$ There may be a bias in the survey results in that all of the years (except 1949) were years of generally rising incomes. The response of families with increases in income during years of generally declining incomes might be different. 
spending of the current years. ${ }^{14}$ The argument seems to be that the peak year of a business cycle establishes a living standard toward which people aspire in subsequent years of lower income. It thus tends to sustain the spending rate in those years. However, if income is moving up gradually and steadily, it soon overtakes the crest of the previous cycle, and from then on previous peak income is merely the income of the preceding year. Since, under the assumptions of this paper, income differences between successive years would be small, in the neighborhood of 2-3 percent in real terms, or 5-6 percent in money terms, the influence of the previous peak would be trivial.

\section{Degree of urbanization}

Since it has been generally observed that at the same levels of income, farm families save more than nonfarm families, continued migration from farms throughout this century is supposed to have lowered the saving ratio. (While there has been no observable secular decline in the national savings ratio, as has been previously pointed out, the effect of a declining farm population might have been offset by some other factor tending to raise the average.)

The decrease in the percent of population occupied with farming is indeed one of the most spectacular of secular economic changes. The relative decline in numbers of unskilled workers is also arresting, however, as shown in Table 6. The proportion of farmers (owners and tenants) fell from 16.5 percent of the "experienced labor force" in 1910 to 10.1 percent in 1940. This decline was matched, however, by a fall in the proportion of unskilled workers (excluding unpaid family workers on farms) of equivalent size. Although data are not available on an exactly comparable basis for 1940 and 1950, we know that these downward trends were accelerated by the war. ${ }^{15}$

14 The relation, as presented by Franco Modigliani, is of the following form: $S_{t}=a+b Y_{t}+c\left(Y-Y_{0}\right)$, in which $Y_{t}$ is the income of the current period, and $Y_{0}$ the income in the previous peak period. (All variables are in constant dollars per capita.) At present, we do not have data for a sufficient number of business cycles to test this proposition empirically. Fitted to the years 1923-40 (using rough estimates of income and saving for the years 1923-28), coefficients are obtained which give a gradually rising secular trend to the saving ratio.

15 Preliminary data from the 1950 census give the following percents of employed persons in these occupational groups: farmers and farm managers, $1940,11.5$ percent, and 1950, 8 percent; laborers (except unpaid family workers and mine workers ), 1940, 11.2 percent, and 1950, 8.8 percent. 
TABLE 6

Socio-Economic Classification of the Experienced Labor Force, 1940, and Gainful Workers, 1910-30

(PERSONS 14 YEARS OF AGE AND OVER)

\begin{tabular}{lrrrr}
\hline & \multicolumn{3}{c}{ PERCENT } & \multicolumn{2}{c}{ DISTRUUTION } \\
WORKER CLASSIFICATION & 1910 & 1920 & 1930 & 1940 \\
\hline \multicolumn{1}{c}{ Total } & 100.0 & 100.0 & 100.0 & 100.0 \\
Professional persons & 4.4 & 5.0 & 6.1 & 6.5 \\
Proprietors, managers, and officials-total & 23.0 & 22.3 & 19.9 & 17.8 \\
Farmers (owners and tenants) & 16.5 & 15.5 & 12.4 & 10.1 \\
Wholesale and retail dealers & 3.3 & 3.4 & 3.7 & 3.9 \\
Other proprietors, managers, and officials & 3.2 & 3.4 & 3.8 & 3.7 \\
Clerks and kindred workers & 10.2 & 13.8 & 16.3 & 17.2 \\
Skilled workers and foremen & 11.7 & 13.5 & 12.9 & 11.7 \\
Semiskilled workers & 14.7 & 16.1 & 16.4 & 21.0 \\
Unskilled workers-total & 36.0 & 29.4 & 28.4 & 25.9 \\
Farm laborers & 14.5 & 9.4 & 8.6 & 7.1 \\
$\quad$ Unpaid family workers & 6.4 & 4.1 & 3.0 & 2.3 \\
Others & 8.1 & 5.2 & 5.6 & 4.8 \\
Laborers, except farm & 14.7 & 14.6 & 12.9 & 10.7 \\
Servant classes & 6.8 & 5.4 & 6.9 & 8.0 \\
\hline
\end{tabular}

The experienced labor force consists of the labor force excluding new workers. The latter are unemployed persons who had not previously worked full-time for one month or more. These concepts do not correspond exactly to those used in the Monthly Report on the Labor Force.

Source: Statistical Abstract of the United States, 1951 (Bureau of the Census).

Much more is known about the saving habits of farm operators than about those of unskilled workers. However, data from the 1949 Survey of Consumer Finances, shown below, indicate that in 1948 the average percent of income saved by unskilled and service workers (including farm laborers) was a fraction of that of farm operators, and considerably below that of the population as a whole. In 1944 and 1950, the frequency of positive savers in this group was lower than that for any other group except retired persons. The ratio of saving to income in 1948 by selected occupational groups, in percent, are as follows:

Professional, managerial, and self-employed 12

Clerical and sales

Skilled and semiskilled

2

Unskilled and service

Farm operators

All spending units

The year 1948 was chosen for computing saving rates, since it 


\section{SPENDING AND SAVING}

seemed as normal from the point of view of farm income as any other in the postwar period. Although the very high saving rate of farmers in comparison with other groups is in large part due to the omission of nonmoney income, it would undoubtedly be above that for any other group even if nonmoney income were included. (In 1941, the percent saved by farm operators was 26 computed on the basis of money income and 18 on the basis of total income. $)^{16}$

Both migrating farm operators and migrating farm laborers presumably left the farms to enter occupational pursuits where income was higher. Farm operators, however, probably moved into groups with lower average and marginal propensities to save, so that even with higher incomes their rate of saving may have declined. Saving considered as a ratio to money income may have declined drastically. Unskilled workers, on the other hand, probably moved into groups with higher incomes and higher propensities to save. Secular shifts in occupational groupings may, therefore, have been to some extent compensating as regards saving.

In order to arrive at the effects on saving of changes in the proportion of earners in different occupations, it would be desirable to know not only from what occupations people come, but what occupations they enter. Secondly, migration may be concentrated at certain income levels. For example, while most agricultural projections assume that under conditions of general prosperity there will be a continued movement of farm populations into towns or cities, these movements will include disproportionately large numbers of low income or marginal farmers. The in-

${ }^{10}$ The ratio in percent of saving to income for farm operator and other groups, including and excluding nonmoney income, as derived from the 1935-36 and 1941 studies, is shown below:

\begin{tabular}{lccccc} 
& \multicolumn{2}{c}{$1935-36^{\mathrm{a}}$} & & \multicolumn{2}{c}{$1941^{\mathrm{b}}$} \\
\cline { 2 - 3 } \cline { 5 - 6 } & $\begin{array}{l}\text { Including } \\
\text { Nonmoney }\end{array}$ & Money & Income & Nonmoluding & Money \\
Income & Only & & Income & Income & Only \\
Farm operators and tenants & 11 & 18 & & 18 & 26 \\
Rural nonfarm & 11 & 12 & & 8 & 9 \\
Urban & 10 & 10 & & 9 & 10 \\
All & 10 & 11 & & 10 & 11
\end{tabular}

a Excludes single-person families.

b Includes single-person families.

Sources: For 1935-36, Family Expenditures in the United States (National Resources Planning Board, 1941), table 40; for 1941, "Spending and Saving in Wartime," Bureau of Labor Statistics Bulletin 822, table 16. 
come of those leaving, and to some extent, those remaining, will presumably be improved by the process. Under these conditions, the net effect is likely to be a rise in the saving rate of these groups.

The effect of community size on saving may be due in large part to the occupational composition which tends to prevail in a community of a given size. Size itself, or degree of urbanization, is probably also important. However, since general economic changes tend to reflect themselves in cyclical variations in the proportion of income received by various occupational groups, and in secular changes in the numbers in these groups, occupational classifications have some advantage over community size classifications as a basis for analysis.

\section{Changes in price level}

It is assumed that, under conditions of continuous full employment, extreme or rapid fluctuations in the price level are excluded. The alternatives are a gradually rising, stable, or gradually declining price level. Despite the fact that a falling price level offers advantages in the way of a more general and perhaps more equitable distribution of the gains of rising productivity, the present trend is for gains in productivity to be shared between wages and profits. Since the difficulties involved in preventing a mild fall in prices from initiating a recessionary movement are great, this alternative will not be discussed here. The difference between an assumption of constant prices and that of gradually but steadily rising prices would probably not affect the rate of saving so much as the type of asset which people would wish to hold.

The effects on saving of a continuing though small rise in prices-say 2 or 3 percent a year-depend mainly on whether the trend is expected to continue. The anticipation of a continued rise in prices of even moderate proportions would reduce the attractiveness of liquid assets and increase the proportion of income placed in personal businesses, corporate equities, homes, and consumer durable equipment. At the same time, the attempt to dispose of liquid assets would put upward pressure on the interest rate.

The interest rate is not entirely the result of free market influences, however. Particularly in an economy committed to the maintenance of high employment, manipulation of the interest 
rate would be one of several instruments available to the government for controlling the level of activity. Thus, a rise in prices might not result in an equilibrating upward movement in interest rates. Under these conditions, gradually rising prices would provide a permanent stimulus to the economy.

The price trends which are embodied in a projection thus emerge, not as a more or less neutral assumption, but as one of the pivotal elements in employment policy.

\section{Changes in stocks of financial assets}

Since a large part of personal saving is not invested directly, but is entrusted to financial institutions or corporations, and since personal saving is generally positive, with asset accumulation exceeding the growth in debt, there has been a secular increase in personal financial assets having varying degrees of liquidity. This growth in liquidity tends to be moderate, but in war years it receives a tremendous impetus from government deficits.

The failure of the ratio of saving to income to rise secularly with the growth in real income has been attributed by some to the compensating effect of the growth in financial assets, which presumably weakens the motive for further accumulation. This hypothesis requires more careful testing after reliable long-term data become available, but it seems unlikely that the net growth in financial assets has much more than kept pace with price increases and the requirements of a higher volume of transactions. If the theory that liquid asset accumulation depresses the rate of saving is true, then the rapid growth in liquidity during wars should be followed by a sharp drop in saving after wars. After World War II, when fixed money value assets rose from $\$ 80$ billion at the close of 1941 to $\$ 198$ billion at the end of 1945 , we should theoretically have had a drop in saving to below the prewar rate. But this did not occur. What did occur was a drop in liquid saving, or a net decline in the liquidity position of the personal economy. In each year, 1947 through 1950, liquid saving (addition to financial assets less growth in debt) was negative. Funds were supplied to individuals from the rest of the economy. Only in 1951 was there a reversion to the more normal pattern of net liquid saving on the part of individuals.

The experience of recent years suggests that a period of abnormally high liquid saving is indeed likely to be followed by one in which liquid saving is much reduced, or even negative, 
but that the total rate of saving may not be similarly affected. Saving may rather be shifted into equities and tangible investments. This shift from financial instruments to direct investments may be as stimulating to the economy as a fall in the rate of personal saving.

\section{Changes in stocks of consumer durables}

In order not to generate cyclical movements, investment must proceed at a rate at which additions to capacity, or the increased flow of output, attain a moving equilibrium with the increased flow of income and demand for output. Expenditures for consumer durable goods are in many respects similar to investment, and give rise to similar problems of attaining equilibrium between flows of expenditure and accretions to stocks. The cyclical behavior of expenditure for consumer durables is closer to that for producer durables than to other types of consumer expenditure. Both are affected by price anticipations which scarcely affect expenditures for perishable commodities or services. While there is nothing in the consumer durable goods area which corresponds exactly to "overcapacity" in producer goods, the market may at times approach temporary saturation.

The "consumption function" has usually been interpreted to mean the relation between income and consumption expenditures, including expenditures for consumer durables (but not for residences). Consumer expenditures are always the passive, dependent variable. Thus, the consumer is either the beneficiary or the victim of the economic drama, but never the hero or villain.

This conception of things is a gross oversimplification, as is indicated by a conspicuous failure in the ability to predict quarterly changes in consumption. ${ }^{17}$ Data from consumer surveys have shown the complexities of consumer behavior, complexities which can only originate in the psychology of the consumers themselves. In the last year or so, the consumer has even appeared to be a speculator, along with the businessman. His "innocence" has disappeared, and, with it, the hope of easy predictions of his behavior.

Nevertheless, we may have to be content for some time with estimating expenditures for perishable goods and services as a function of the flow of current income. Durable and even semi-

\footnotetext{
${ }^{17}$ See Robert V. Rosa, "Use of the Consumption Function in Short-Run Forecasting," Review of Economics and Statistics, Vol. xxx, 1948, p. 97.
} 


\section{SPENDING AND SAVING}

\section{CHART 1}

Expenditures for Consumer Nondurable Goods and Services,

Consumer Durables, and Producer Durables, 1929-51

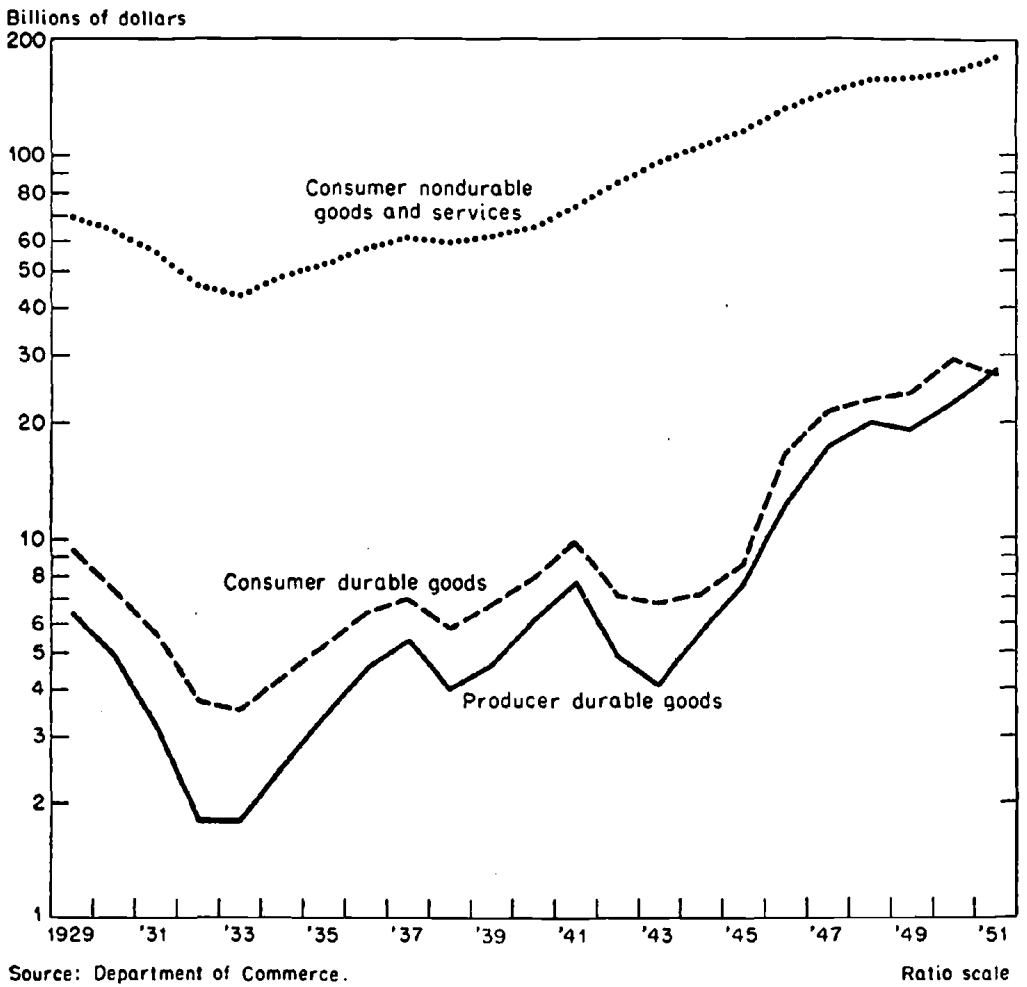

durable goods expenditures, on the other hand, must be classed with investments as variables which are often responsive to changes in income, but may be more vitally affected by stocks on hand and speculative influences. ${ }^{18}$

18 This statement will be no surprise to persons working on current estimates of gross national product, or projections for the next 6 to 18 months. In such projections it has become customary to "move" nondurables and services with wage and salary and transfer incomes, and to estimate durable goods expenditures independently, along with investment and government expenditures. On the other hand, the level of wage and salary incomes (which theoretically should be estimated from the multiplier after the exogenous variables have been determined) now is determined to a very considerable extent by wage bargaining, and the spread of the current wage pattern, considering the expected strength of demand for labor, is an important additional consideration. The number of exogenous variables considered in short-range models is gradually being enlarged. 
The accumulation of stocks of durable goods may tend to slow down the rate of expenditure on durable goods while income is yet stable or expanding. At some times, moreover, expenditures for consumer durable goods represent a rearrangement of accumulated savings among different types of assets, rather than an increase in consumption. There was a large element of this type of activity in consumer behavior during the nine months following the Korean invasion. The wave of spending for durable goods did not represent an increase in the propensity to consume so much as the desire to exchange assets which were expected to depreciate in value for assets which would rise in value. In this context, a distinction between "expenditures" and "consumption" is useful. "Expenditures" are influenced by fluctuations in prices and speculative considerations to a much greater extent than "consumption."

One reason that the difference in the characters of durable and nondurable goods expenditures has been overlooked in determining the consumption function is the implicit assumption that a reduction of durable goods expenditures would mean an equivalent increase in demand for other, less durable goods or services. ${ }^{19}$ To some extent, this compensating effect undoubtedly does occur. Nevertheless, to assume that there is complete "spill-over," or one-to-one substitution, overlooks the large element of saving in expenditures for durable goods. A spontaneous decline in durable goods demand will in the main be associated with a tendency to save more in other ways. At a minimum, dissaving will decrease. Although the relations between changing durable goods expenditures and saving are difficult to observe in time series, due to simultaneous changes in income, data on individual spending units confirm the fact that durable goods purchases are an important cause of dissaving. The 1950 Survey of Consumer Finances says: "In 1949, although a year of some downward economic readjustments, purchases of automobiles and other durable goods reached record levels. These increased purchases, although apparent among both savers and dissavers, were more numerous in the latter group. Almost two-thirds of all dissavers purchased some type of durable good, while less than one-half of all positive savers made such purchases. These purchases apparently moved many spending units into the dissaving category." ${ }^{20}$

19 See, for example, Lawrence Klein, "Post-Mortem on Transition Predictions of National Product," Journal of Political Economy, August 1946. 20 Part Iv, page 50. 
A projection which is merely a spot picture of the economy at some time in the future, say, 10 or 20 years hence, need not concern itself with the effects of present stocks on the future stream of purchases. If the objective, on the other hand, is to indicate the rate of expenditure on durable goods conducive to continuous full employment, both present stocks and equilibrium rates of accumulation must be considered. Determining an equilibrium rate of accumulation for consumer durables is probably about as difficult as determining it for producer goods; with a given income and range of products, relative saturation is indeed possible, but changes in the style and type of durable goods available cause the rate of obsolescence on existing durable equipment to vary unpredictably. Data problems are also important. While there is considerable information on stocks and the age distribution of automobiles, and on the number and condition of homes, little is known about other consumer durables or semidurables.

Housing is the one area where demographic factors and consumption standards provide a somewhat more adequate definition of the problem. Estimates of the number of additional housing units required by a given date to take care of the formation of new families and families currently "doubled up" can be derived from population forecasts. To this must be added an estimate of the number of substandard units which should be replaced in a given time interval. ${ }^{21}$ The numbers here depend mainly on the content of government programs providing assistance for slum clearance and urban redevelopment. Under any assumptions, however, there is a fairly definite ceiling to the rate of new housing construction which can be sustained, even with rising income, as well as a lower limit as to what "should" take place within a given time span.

Assigning a horizon to additions to stocks of consumer durables is somewhat more of an uncharted enterprise. Automobiles, of course, are the major item of concern. The age distribution of stocks of automobiles is known approximately, but the importance of this knowledge is impaired by the fact that the age at which automobiles are retired is fairly elastic, and depends upon economic conditions as well as technological factors. Still, an ap-

21 Official estimates of the size and scope of the housing problem can be found in How Big Is the Housing Job? issued by the Housing and Home Finance Agency, October 1951. 
praisal of the feasibility of continuing a given rate of production of automobiles can be made by considering such factors as population growth, population movements, trends toward urbanization, and the number of cars owned by wealthier income classes. In the Council of Economic Advisers projection for 1958, a cursory analysis indicated that an annual addition of between 4 and 5 million automobiles (after the postwar backlog is worked off) would be a reasonable estimate for the next 10 years. Stocks of furniture and household appliance expenditures are related to new family formation and to new housing construction, as well as to technological advance. The extension of electricity to rural areas and the number of localities which can receive television are further pertinent data.

\section{F. PROBLEMS OF PROJECTING SPENDING AND SAVING}

Part of the deficiencies of both the analysis of consumer behavior and attempts at projections has been that both have been cast largely in terms of the national income and product accounts, which are not entirely appropriate either to the study of consumer behavior or to economic models. Secondly, the decision to save has been interpreted as depending on the psychology of the consumer, and on economic changes which affect consumers' incomes and expectations without consideration of the role that financial institutions play in determining the pattern of consumer outlays. The effect of changes in terms on which credit is available and in the types of instruments available for saving has been largely ignored. Some modifications in the approach to "projecting" consumer behavior, and to economic projections in general, are discussed below.

\section{Concepts of spending and saving and consumer behavior}

In the analysis of spending patterns of consumers, through budget data, the proper definition of income has received considerable attention, both in relation to the items which should be included and the time period over which income should be reckoned. As has frequently been pointed out, the relation between a family's income and its consumption pattern may depend less on actual income over some more or less arbitrary period than on what the family regards as its income or its "normal" income. 


\section{SPENDING AND SAVING}

It is equally essential to know what the family regards as saving. While the behavior of a consumer may not always be rational, even in terms of his own concepts and objectives, the study of motivations must at least start with a knowledge of what these objectives are, and how a given expenditure or asset acquisition fits into the scheme the consumer has in mind.

Questions thus suggest themselves as to what concept of saving is most closely related to consumers' motivations. Should such items as depreciation on homes and cars, additions to equities in life insurance, contributions to private and public pension plans be included in saving?

Probably there is no way of answering these questions except by consumer surveys, directly addressed to finding out how consumers themselves define saving (which may be different from the way they say they define it). An alternative approach would be to experiment with several different definitions of saving. A beginning was made in this direction in the 1950 Survey of Consumer Finances. The "standard" definition used in these surveys does not include additions to stocks of any type of consumer durable goods. Computations for 1949 were made on an alternative basis, including purchases of new automobiles (less depreciation) as saving. The alternative also included an item for depreciation on homes not carried in the "standard" computations.

The importance of knowing what the spending unit itself regards as its saving stems partly from the fact that the institutions through which saving takes place are changing. Private industrial pension plans are becoming of increasing importance, and are currently adding over a billion dollars a year to personal saving. If the consumer regards contributions to these funds as saving (or, more importantly, if he considers that the sum of both employer and employee contributions are the equivalent of his own saving), this will affect his decisions regarding the proportion of income he wishes to place in other types of assets. Since a predominant motive for saving on the part of families of low and moderate means is provision for old age, social arrangements which provide more or less automatically for old age security will have the effect of diminishing those types of saving subject to voluntary control.

Attitudes toward life insurance are also worth exploring. The 1950 Survey of Consumer Finances uncovered the fact that 77 percent of all spending units in 1949 had some form of life insurance, compared with only 69 percent owning liquid assets, 


\section{SPENDING AND SAVING}

and 55 percent owning automobiles. However, since it was also found that few units owning life insurance have any idea of the annual change in their equity, it seems likely that many regard their total premium as saving, and may thus tend to overestimate their current saving rate, while others probably regard insurance entirely as current expense.

Imputed items of expenditure, now included in the income and product accounts, raise similar definitional problems. For example, failure on the part of home owners to consider depreciation or undermaintenance as dissaving may not be important from the point of view of long-range analysis, but it would be important in causing spending for repair at various stages of the business cycle to deviate from that which might be expected were an annual allowance for repair and maintenance carried in the householder's personal accounting.

\section{Personal saving and sources and uses of funds}

The neglect of such factors as changes in the terms on which consumers can attain credit for homes or durable goods probably stems mainly from the lack of a systematic set of historical estimates incorporating the components of saving and expenditures into a complete distribution of sources and uses of personal funds. Such a series of estimates would appear to be a requisite first step for an analysis of the effects of changes originating in agencies supplying or absorbing funds. A second reason for the neglect of adequate study of financial institutions is that much of the analysis of consumer behavior has proceeded from crosssection studies of consumer budgets collected at intervals of several years and without explicit comparison of the financial environments in the different sampling periods.

It can scarcely be doubted, however, that changes in methods of financing have had important consequences modifying the pattern of personal expenditures-consequences which have by no means been confined to that group of consumers who own and operate farms or personal businesses. The most far-reaching modification in financing methods in recent experience lies in changes in the character of home mortgages and mortgage institutions since the Home Owners' Loan Corporation began operations in the thirties. Previous to that time the unamortized home loan was the exceptional case. While mortgage renewals might be contingent upon satisfactory reductions in principal, the records of the HOLC indicate that many lending institutions 


\section{SPENDING AND SAVING}

renewed mortgages time after time in the amount of the original loan. In the postwar period government guarantees were of course extended only to loans with amortization provisions, and this became the accepted practice for all mortgage contracts. However, lower interest rates and lengthened maturities in recent years have brought down the monthly cost of the amortized loan to a level within the reach of middle income groups, and often to the level of the unamortized loan of 20 years earlier. This has stimulated home purchases, as has the extension of government guarantees to mortgages involving little (or no) owner equity. For these and other reasons, there has been a sharp swing to home ownership since the war, and almost every mortgage has carried with it a contract for stipulated annual saving. The rate of contractual saving, and probably of total personal saving, will be affected by these developments for years to come.

The growth of facilities for consumer instalment credit is a second important institutional development affecting saving and consumption patterns. Its main effect may be to move forward in time expenditures that would have been made later, and at a somewhat lower cost. It would also seem a priori that the availability of ready credit would increase the proportion of income used for purchase of durable goods and other relatively expensive items. The use of instalment credit also appears to increase the amplitude of cyclical swings in consumption, since, when income drops, the rise of new credit declines, while contractual repayments continue.

The effectiveness of credit mechanisms and their growing pervasiveness indicate that while national income accounts can measure the increase in wealth due to saving, or changes in personal net worth, the analysis of saving must rest in a more comprehensive framework.

Fortunately, the deficiency of historical statistics on sources and uses of funds is now being at least partially rectified by the preparation of a series of estimates by the Federal Reserve Board covering the years 1939 to date. The logic of this series naturally requires that the sources and uses of funds of the financial institutions through which savings flow be presented separately. In addition, the accounts of consumers are being separated from those of personal businesses through estimates of entrepreneurial investments and withdrawals. 


\section{SPENDING AND SAVING}

The separation of insurance agencies, banks, trust funds, etc. from natural persons and nonfinancial corporations permits study of the effects of the policies of these institutions on the flow and distribution of saving. The separation of the accounts of households from those of personal businesses or farm enterprises is also desirable, but statistically very difficult. Since the assets and liabilities of a household are interchangeable with those of a personally owned business, in many cases it is difficult to tell whether a given financial change originates in the producer or the consumer area.

Budgetary data disclose that families owning businesses have special characteristics, such as fluctuating incomes and high propensities to save. ${ }^{22}$ Setting forth and studying in more detail the financing of private businesses may disclose the types of change that originate in the business and affect the household secondarily.

\section{Conclusions}

If academic economists have erred on the side of neglecting the effect of institutions on saving, government economists may err in the opposite direction, losing sight of the fact that to some unknown, but significant, extent, there are psychological laws or "propensities" dictating the division of income between "spending" and "saving." Government or institutional policy usually deals not with saving, as such, but with some specific component of saving. The effects of policies focused on some institution or credit arrangement on the over-all rate of personal saving may sometimes be disregarded as negligible, but at other times an implicit assumption is involved that an expansion or contraction in some component of saving will cause a similar movement in

22 Entrepreneurial groups have higher average, and probably higher marginal, propensities to save, although, as was pointed out by Ruth Mack in her article in the Review of Economics and Statistics previously cited, part of observed differences between the marginal propensities to save of various occupational groups may be due to the fact that the modal income and the income range vary among different occupations. Thus, at a given income level, different occupational groups will not be comparable with respect to the proportion of units having income increases or declines.

A priori, one would expect saving to be higher at a given income level for entrepreneurial groups, because in addition to the ordinary motives for saving, the businessman or farmer has the incentive that new equipment may mean not only profits but more pleasant ways of performing his tasks and more pleasant work surroundings. In this respect, investment in farm equipment resembles investment in consumer durables, which not only saves the housewife's time, but changes the character of her work. 


\section{SPENDING AND SAVING}

total personal saving. For example, the restrictions embodied in Regulation $\mathrm{W}$, governing the terms of instalment credit, rested partly on the belief that a curtailment of dissaving in this area would lead to a temporary increase in total saving. Only on this basis could the measure be described as anti-inflationary.

The operational, or policy, approach suggests that research could most fruitfully be centered on those aspects of personal behavior which are most variable and responsive to general economic movements. For example, it may be more important to know the extent to which saving responds to changes in farm income and prices, which are volatile, than to know how it is related to the size distribution of income, which seems very stable.

Intensive study of the entrepreneurial group is especially important. Whatever may be the relation of the saving patterns of this group to other segments of the population at a given time, shifts in saving as economic fluctuations occur are undoubtedly more extreme among entrepreneurs than among other occupational groups. Further, changes in credit policy and financial institutions probably have their maximum impact on farmers and businessmen.

The relation between economic changes and shifting of families between income groups is also important in saving analysis. The stability of the size distribution of income from year to year conceals the high degree of income variability among families comprised in the distribution. An index of the degree of shifting within the income distribution by reason of migrations of families up or down the income scale is needed to supplement our indexes of the change in aggregate money and real income. The variability of income for individual families is known to be a major determinant of saving behavior, but at present we do not know how much shifting about occurs under normal conditions, or the amount of saving or dissaving in each income group which can be attributed to this factor. Consequently, we are ignorant of the extent to which wealth is redistributed through adjustments in saving (or dissaving) in response to fluctuations in family income. We do not even know whether the extreme concentration of saving at upper income levels is causing an increase in the concentration of wealth. This is an important gap in the economics of welfare, as well as in our understanding of the degree to which the normal operation of the economy tends to maintain or restore conditions of equilibrium. 